Department of

Economics and Finance

Ahmed A. Alzahrani and Andros Gregoriou

Can Market Frictions Really Explain the Price I mpact Asymmetry of Block Trades? Evidence from the Saudi Stock Market

March 2010 


\title{
Can Market Frictions Really Explain the Price Impact Asymmetry of Block Trades? Evidence from the Saudi Stock Market.
}

\author{
Ahmed A. Alzahrani \\ Department of Economics and Finance, Brunel University \\ Andros Gregoriou \\ Norwich Business School, University of East Anglia
}

\begin{abstract}
We empirically examine the price impact of block trades, in the Saudi Stock Market over the time period of 2005-2008. Using a unique dataset of intraday data consisting of 2.3 million block buys and 1.9 million block sales, we find an asymmetry in the price impact of block purchases and sales. The asymmetry persists even when we account for the bidask bias in block trades, which is contrary to the previous literature. Overall, our findings suggest that in an emerging market where institutional trading is relatively scarce, market microstructure cannot explain the asymmetry in the price impact of large trades.
\end{abstract}

JEL classification: G10, G14

Keywords: Saudi Stock Market, Bid-Ask Spreads, Block Trades, Intraday Data.

October 2009 


\section{Introduction}

The proportion of equities traded in blocks has increased substantially in recent years. In 1994, block trades of 10,000 shares accounted for 55.5\% of New York Stock Exchange (NYSE) share volume (Madhavan and Chang, 1997); now it accounts for over $70 \%$. In the LSE (London Stock Exchange) block trades (of 10,000 shares or more) accounted for mere $5 \%$ of total FTSE 100 trading volume in 1984 which reached over $50 \%$ in $2005 .^{1}$ Institutional trading, predominately made up of block trades, accounts for over $60 \%$ of total trading volume in the LSE (Stapledon, 1996).

Prior empirical research has documented a permanent price impact asymmetry between buyer and seller initiated trades in many equity markets including the NYSE (Holthausen et al.,1987) NASDAQ (Choe et al.,1992), DJIA, (Frino et al, 2003), LSE, (Gemmill, 1996 and Gregoriou, 2008) and the Australian stock exchange, (Aitken and Frino, 1996 and Chiyachantana et al, 2004). The price impact asymmetry between block purchases and sales has been a "Puzzle" over the last three decades. Empirical work (see among others, Holthause et al., 1987, 1990; Keim and Madhavan, 1996; Gemmill, 1996, Frino et al, 2003 and Gregoriou, 2008) has suggested that stock prices react differently to buy and sell orders. ${ }^{2}$ The price continuation following a block purchase and a price reversal following a block sale suggests that block sellers pay liquidity premium while block buyers do not (Aitken and Frino, 1996).

The explanation of the asymmetry of the price impact of block trades is that there is more informed trading in purchases then in sales. Chan and Lakonishok (1993), Keim and

\footnotetext{
${ }^{1}$ The Financial Times, January 2006.

${ }^{2}$ Chan and Lakonishok (1993) call the price asymmetry of block trades a "key puzzle".
} 
Madhavan (1996) and Saar (2001) among others suggest that the block purchases are based on the arrival of new firm-specific information, whereas block sales are motivated by liquidity and portfolio composition. The decision to sell a block reflects the limited option a trader has among stocks in his/her portfolio, whereas the decision to buy a block indicates a fundamental interest in that particular stock among many stocks in the market.

This paper examines the price impacts of buyer and seller initiated block trades on the Saudi Stock Market (SSM) over the time period, 2005-2008. This is important for a number of reasons. First, to our knowledge this is the first study to investigate the price impact of block trades in an emerging equity market. Emerging markets are of particular interest because a vast majority of mutual funds, investment banks and individuals are investing heavily in emerging markets to diversify risk. This is common given that institutional investment is not very well established in emerging equity markets. Second, the SSM is of particular interest because there have been a large number of structural changes affecting the microstructure of the equity market, as well as the role the exchange plays as a resource allocation mechanism. The major structural change was when the government established the Capital Market Authority (CMA) in 2004. The CMA is a centralised regulatory body that oversees the market regulation and activities of the SSM.

Our empirical findings reaffirm the previous literature by documenting a greater price impact of block purchases then block sales. However, unlike the previous literature we discover that the asymmetry persists even when we account for the bid-ask bias in block trades. Overall, our findings suggest that in an emerging market where institutional 
trading is relatively scarce, market microstructure cannot explain the asymmetry in the price impact of large trades.

The paper is organized as following. Section 2 provides a detailed description of the Saudi Stock Market. Section 3 illustrates the data and methodology used to implement the empirical analysis. Section 4 documents a price impact asymmetry between block purchases and sales on the Saudi Stock Market. Section 5 empirically examines whether the bid-ask spread can explain the asymmetry between block purchases and sales found in Section 4. Finally, Section 6 summarizes and concludes.

\section{The Saudi Stock Market (SSM)}

The SSM is a pure order-driven market where only common stocks are traded with financial derivatives and short selling not allowed in the market. In 2008, individual trading amounted to $92 \%$ of all trading volume, implying that institutional trading is negligible in the SSM. Nonetheless, it is an extremely active stock exchange with respect to trading volume and market capitalization compared to other regional equity markets. ${ }^{3}$ As we can witness from Table 1 the SSM has experienced tremendous growth in market value, number of listed firms and trading volume over the time period 2002-2008. For instance, the number of shares traded and number of transactions have grown remarkably in the last seven years averaging $165 \%$ and $175 \%$ respectively. It is of great importance

3 SSM is by far the largest stock exchange in terms of market capitalization and trading volume in the Middle East region. According to the Arab Monetary Fund's annual for the year 2008, which provides statistics for 15 stock markets in the Middle East, the capitalization of the SSM represents $41 \%$ of the total market capitalization, and the value traded of the SSM represents $67 \%$ of the total stock value traded in all member markets. 
to both academics and practitioners to investigate the price impact of buyer and seller initiated trades in an emerging stock market that is growing exponentially.

Table1: Saudi Stock Market Main Indicators.

\begin{tabular}{lcccccc}
\hline Year & $\begin{array}{c}\text { No. of } \\
\text { Investors }\end{array}$ & No of Firms & $\begin{array}{c}\text { No. of } \\
\text { Shares traded } \\
\text { millions }\end{array}$ & $\begin{array}{c}\text { No. of } \\
\text { transactions } \\
\mathbf{0 0 0}\end{array}$ & $\begin{array}{c}\text { Market Value } \\
\text { in Billions } \\
\text { (Saudi Riyal) }\end{array}$ & $\begin{array}{c}\text { Index } \\
\text { (Value- } \\
\text { weighted) }\end{array}$ \\
$\mathbf{2 0 0 2}$ & N/A & 68 & 1,735 & 1,033 & 280 & 2,518 \\
$\mathbf{2 0 0 3}$ & N/A & 70 & 5,565 & 3,763 & 589 & 4,437 \\
$\mathbf{2 0 0 4}$ & $1,383,636$ & 73 & 10,298 & 13,319 & 1,148 & 8,206 \\
$\mathbf{2 0 0 5}$ & $2,573,597$ & 77 & 12,281 & 46,607 & 2,438 & 16.712 \\
$\mathbf{2 0 0 6}$ & $3,577,618$ & 86 & 54,440 & 96,095 & 1,225 & 7,933 \\
$\mathbf{2 0 0 7}$ & $3,669,538$ & 111 & 57.829 & 65,665 & 1,946 & 11,176 \\
$\mathbf{2 0 0 8}$ & $3,798,316$ & 126 & 58,727 & 52,135 & 924 & 4,803 \\
\hline
\end{tabular}

Notes: Year of Trade, Number of investors present in the Saudi Stock Market, Number of Shares Traded, Number of Transactions, Market Value in Billions, and a Value Weighted Index for the Saudi Stock Market. Forty fourth Annual Reports. The exchange rate is approximately ( $\$ 1=3.75$ Saudi Riyal). Source: SAMA.

\section{Data and Econometric Methodology}

We use high frequency data at one minute time intervals to evaluate the price impact of buyer and seller initiated block trades, in the SSM over the time period of January 2005 to September 2008. The data is taken from Mubasher, a vendor of quotes and transaction data in the SSM. It is a unique dataset because to our knowledge it is the only database that includes all listed companies (124 companies) in the SSM and the market index, Tadawul All Share Index (TASI) at the intraday level. The dataset contains all transactions which are time-stamped to the nearest minute and in some cases it aggregates all transactions occurred within the minute. Any inference about the data is 
applicable to the whole market as the dataset is free from any sample bias. ${ }^{4}$ It is a highly comprehensive dataset as it almost covers four-year intraday dataset, from Jan 2005 to September 2008, with over $16,076,414$ records of all transactions and bid-ask quotes. Following the previous literature (see among others Madhavan and Cheng, 1997) we define block trades in our study as any trade with over 10.000 shares, which is 4,221 , 870 trades or $20.8 \%$ of all trades in our sample. Clearly, the sample size, when compared with those used in previous studies, is very large. For example, Frino et al. (2003) and Gregoriou (2008) used approximately 2,800,000 block trades, Chan and Lakonishok (1993) examined 1,215,387 transactions while Madhavan and Cheng (1997) and Gemmill (1996) analysed only 16,343 and 6,000 trades respectively.

Following the previous literature (see among others Madhavan and Cheng, 1997), block trade price effect are classified into three categories, the total price impact, temporary price impact and permanent price impact. We use a five trade "minutes" benchmark to compute the price effects. ${ }^{5}$ The total price impact is calculated as the percentage return from five trades prior to the block trade to the block trade itself. The temporary price impact is calculated as the percentage return from the block trade to the fifth trade after the block trade. The permanent price impact represents the percentage return from five trades prior to the block trade to five trades after the block trade. Because quotes data are not directly available in the Saudi market, all prices used in the computations are transaction prices.

\footnotetext{
${ }^{4}$ Two companies were delisted due to pending satisfaction of certain financial criteria, namely "Bisha" and "Anaam". They were excluded from the data because no transaction data was available due to the suspension of trading.

${ }^{5}$ Given that we use intraday minute transactions data, we use the terms trades and minutes interchangeably.
} 
The following equations represent the three types of price effect used in this study:

Total Impact $=\frac{\text { Close }_{t}-\text { Close }_{t-5}}{\text { Close }_{t-5}}$

Temporary Impact $=\frac{\text { Close }_{t+5}-\text { Close }_{t}}{\text { Close }_{t}}$

Permanent Impact $=\frac{\text { Close }_{t+5}-\text { Close }_{t-5}}{\text { Close }_{t-5}}$

We use the trade classification algorithm established by Lee and Ready (1991) to identify the block purchases and sales. The idea underlying the Lee and Ready method is to infer the trade direction of the transaction using the "tick rule". The tick rule test compares trade price changes relative to previous trade prices. If the price change between trades is positive, then the transaction is coded as a buy-initiated trade. A negative price change yields a sell-initiated trade. We follow the Bonser-Neal et al. (1999) method to sign a trade when the change in the price is zero. We compare trade price $P(t)$ with the trade price $P(t-2)$ and if the change in price is still zero, we repeat the process until we find a difference in prices. If the price change is still zero at $P(t-5)$ then this trade is unclassified and omitted. Using the "tick rule", we classify 2,366,099 trades into buy trades and 1, 855,236 into sell trades with total sample number of 4,221,870 transactions. Consistent with prior research, we associate a trade indicator for each trade to indicate the nature of the trade: 1 (buy), -1 (sell), or 0 (undecided).

Table 2 reports descriptive statistics for our dataset. The dataset contains intraday one minute transaction data of all companies in the SSM making up the TASI index. Each one-minute interval includes the following fields for each trade: Ticker, Date, Time, Price 
Ask, Bid, and Volume. ${ }^{6}$ We analyse $4,221,870$ transactions amounting to a value of S.R 8.7 trillion (equivalent to $\$ 2,32$ trillions). The sample is very large comparing to previous studies and it covers all 124 listed companies. The average number of shares per trade is larger for purchases amounting to 29,130 shares whereas the average number of trades for sales is 28,204 shares. Moreover, the average quoted spread defined as the ask price minus the bid price, is slightly higher for purchases (S.R 0.3607 then for sales (S.R 0.3564). On the other hand, the relative spread defined as the ask price minus the bid price, divided by the midprice (the average of the bid and ask prices), indicates that the spread is larger in the sale trades than in the buy trades; however, the difference is negligible. Comparing block trades to all trades, we can infer that quoted spread might be a function of the trade size because for all trades the average quoted and relative spreads are almost half of those found in block trades. One explanation to this might be that large traders prefer to deal with larger and more established companies listed on the SSM. The SSM firms experience higher prices, suggesting that large trades have higher price impact and transaction cost reflected in the spread. The Trade Size of the trade can be seen as a proxy of the information content of the order. Easley and O'Hara (1987) indicate that informed traders prefer to trade a large amount at any given price, a finding that confirmed by many researchers. ${ }^{7}$ Consequently, informed trading is believed to have a higher effect on price impact and the bid-ask spread.

\footnotetext{
${ }^{6}$ We follow (Engle and Russell, 1998, and Spierdijk, 2004) and treat multiple transactions at the same time as one single transaction with aggregated trade volume and average prices.

${ }^{7}$ See among others Kyle (1985), Admati and Pfleiderer, (1988), Subrahmanyam, (1991).
} 
Table 2. Summary Statistics of Block Purchases and Sales for the Saudi Stock Market.

\begin{tabular}{llcccc}
\hline & $\begin{array}{l}\text { No of trades } \\
\text { '05-‘08 }\end{array}$ & $\begin{array}{c}\text { Avg No of } \\
\text { shares }\end{array}$ & $\begin{array}{c}\text { Avg Value } \\
\text { Per trade } \\
\text { ( Saudi Riyal) }\end{array}$ & $\begin{array}{c}\text { Avg Quoted } \\
\text { Spread }\end{array}$ & $\begin{array}{c}\text { Avg Relative } \\
\text { Spread }\end{array}$ \\
All trades & $\mathbf{1 6 , 0 7 6 , 4 1 4}$ & $\mathbf{9 , 5 2 8}$ & $\mathbf{5 8 , 0 0 0}$ & $\mathbf{0 . 1 9}$ & $\mathbf{0 . 0 0 3 0}$ \\
Block trades & $\mathbf{4 , 2 2 1 , 8 7 0}$ & 29,130 & $\mathbf{1 , 8 8 0 , 4 7 3}$ & $\mathbf{0 . 3 5 8 6}$ & $\mathbf{0 . 0 0 6 3}$ \\
Block Buys & $\mathbf{2 , 3 6 6 , 0 9 9}$ & $\mathbf{3 0 , 0 4 6}$ & $\mathbf{1 , 9 3 2 , 4 5 2}$ & $\mathbf{0 . 3 6 0 7}$ & $\mathbf{0 . 0 0 6 2}$ \\
Block Sells & $\mathbf{1 , 8 5 5 , 2 3 6}$ & $\mathbf{2 8 , 2 0 4}$ & $\mathbf{1 , 8 2 7 , 4 6 6}$ & $\mathbf{0 . 3 5 6 4}$ & $\mathbf{0 . 0 0 6 4}$ \\
\hline
\end{tabular}

Notes: Number of trades, average number of shares traded, average value per trade, average quoted spread where quoted spread is defined as the ask minus the bid price, and the average relative spread defined as the ask price minus the bid price, divided by the midprice (the average of the bid and ask prices). The exchange rate is approximately ( $\$ 1=3.75$ Saudi Riyal).

\section{4. $\quad$ Price Impact Asymmetry}

In Table 3 we formally test whether the magnitude of the price impact of buyer and seller initiatedblock trades is significantly different. Our test entails a comparison of the mean for the temporary permanent and total price impacts of block purchases and sales. The asymmetry between block purchases and sales reported in the previous literature is transparent when we observe the permanent and total price impact. Block buys have a permanent (total) price impact of $0.49 \%(0.51 \%)$, whereas block sales have a permanent (total) price impact of $-0.38 \% .(-0.43 \%)$. Tests of equality in all three measured price impacts demonstrate that block purchases have a significantly greater price impact than block sales. The price impact asymmetry gives strong support that the information content of block purchases is higher than block sales. This is because the. SSM has few institutional investors and a vast majority of the governmental mutual funds are not active in the market. The mutual funds primarily follow a buy-and-hold investment strategy, 
implying that the market has more purchases than block sales. The purchase of a large trade in the SSM is perceived as a fundamentally strategic decision, whereas the sale of a large trade is perceived as less strategic decision or liquidity- based decision.

The temporary price impact which is mainly a product of short-run liquidity costs suggests that following a block sale, a reversal in prices is predicted and that the magnitude of price reversal is higher in block sales than block purchases. The higher reversal in the price impact for block sales at $0.04 \%$, suggests that sellers in the SSM pay a liquidity premium that is at least three times the liquidity premium paid by buyers at $0.013 \%$. The best five quotes for the bid and ask prices are transparent in the SSM and trades seem to react to a large block sale before it is executed through discounting the price at $-0.42 \%$. Once the block sale has been executed, a price reversal of $0.04 \%$ on average is observed. On the other hand, block purchases are executed at a $0.5 \%$ premium with a smaller price reversal of $-0.01 \%$. Given that the price impact continuation is higher in the block purchases, the results suggest that block buys are more informative than block sells. Our results are consistent with the prior literature. See among others, Chan and Lakonishok (1993) and Keim and Madhavan (1995).

Table 3. Transaction Price Effects of Block Trades in the Saudi Stock Market.

\begin{tabular}{lccc}
\hline Panel A Buys $(\mathbf{n = 2 , 3 6 6 , 0 9 9 )}$ & $\begin{array}{c}\text { Permanent } \\
\text { effects }\end{array}$ & $\begin{array}{c}\text { Total } \\
\text { effects }\end{array}$ & $\begin{array}{c}\text { Temporary } \\
\text { effects }\end{array}$ \\
Mean & & & $\mathbf{0 0 0 1 3 7}$ \\
SD & $\mathbf{. 0 0 4 9 1 7}$ & $\mathbf{. 0 0 5 0 6 6 7}$ & $\mathbf{- . 0 0 0 1 3 7}$ \\
\end{tabular}




\begin{tabular}{lccc}
\hline Panel B Sell(n=1,855,236) & & & \\
Mean & $\mathbf{- . 0 0 3 8 8 3}$ & $\mathbf{- . 0 0 4 2 6 7 8}$ & $\mathbf{. 0 0 0 4 0 1 2}$ \\
SD & .01246 & $\mathbf{. 0 0 9 7 6 1 1}$ & $\mathbf{. 0 0 9 5 2 5 1}$ \\
Panel C Test of Equality & & & \\
Mean difference & $\mathbf{0 . 0 0 1 0 3 4}$ & $\mathbf{0 . 0 0 0 7 9 9}$ & $\mathbf{0 . 0 0 0 2 6 4}$ \\
$\begin{array}{l}\text { t-statistic(two-sample mean comparison } \\
\text { test) }\end{array}$ & $\mathbf{5 8 5 * * *}$ & $\mathbf{7 9 4} * * *$ & $-\mathbf{4 7} * * *$ \\
& & & \\
\hline
\end{tabular}

Notes: Transaction returns surrounding block trades of 10,000 shares or more executed on all companies listed on the Saudi Stock Market over the time period 2005-2008, broken down by buyer (Panel A) and seller (Panel B) initiated trades. Three measures of price impact are reported :(1) Permanent, defined as the algorithmic return of transaction prices from five trade before the block to five trades after;(2) Total, defined as the algorithmic return of transaction prices from five trade before the block to the block trade; and (3) Temporary, defined as the algorithmic return of transaction prices from the block to five trades after the block trade. Panel A reports the buy-block traders while Panel B reports sell-block trades along with mean and standards deviations. Panel $\mathrm{C}$ shows the tests of equality between the two samples by performing a two-sample mean comparison $\mathrm{t}$ test. Standard errors are reported in parentheses. *** Significant at the $1 \%$ level.

\section{Price Impacts and the Bid-Ask Spread}

There is an emerging literature (Frino et al, 2003 and Gregoriou, 2008) that attempts to explain the price impact asymmetry in block purchases and sales by the bid-ask bias in stock prices. This is because when using transaction prices to calculate the price impact of block trades a systematic error occurs. This is due to the fact transaction prices, implicitly, assume an equal probability of a trade to occur at the ask or at the bid price. In order to mitigate this systematic error Frino et al. (2003) and Gregoriou (2008) have computed the price impact of block trades purged of bid-ask bias. This is done by using quote data to calculate price returns where bid prices are used to calculate price returns for the sell trades and ask prices for the buy trades. Frino et al (2003) and Gregoriou 
(2008) find that the asymmetric price impact of block purchases and sales is diminished in the DJIA and the LSE respectively, when price impacts are purged of bid-ask bias.

Therefore, following this line of literature, we empirically examine whether the price impact asymmetry between block purchases and sales in the Saudi Stock Market, can be explained by the bid-ask bias. Following Lease et al. (1991), Frino et al (2003) and Gregoriou (2008) we calculate the order flow ratio, to examine the propensity to trade at the quote. We document the frequency of trading for five classifications; 1) at the bid price indicating a block sell, 2) at ask price indicating a block buy, 3) at the midprice price indicating a matching order, 4) between the midprice and bid prices indicating selling pressure, 5) between midprice price and ask prices indicating buying pressure. The order flow ratio is calculated for the entire sample using the following formula:

Order Flow Ratio $=\frac{(\text { Ask }- \text { Price })}{(A s k-B i d)}$

As the order flow ratio approaches 1 , it is more likely the trade price is at the bid price, and when it reaches 0 , the greater the likelihood that the trade is at the ask price .Table 4 evaluates the percentage of block trades occurring at the ask and bid prices in the Saudi Stock Market over the time period, 2005-2008. 40\% of the block trades take place at the ask prices whereas $37 \%$ of trades occur at the bid prices. Moreover, the trades that happen between the midpoint and either the ask or bid prices have similar percentages, $9 \%$ and $7 \%$ respectively. Given that the number of block purchases are higher, and the distribution of the percentages of trading at the ask and bid price are similar, indicates a 
propensity to trade at the ask or between the midpoint and ask more frequently than at the bid price.

Table 4. Block Prices Relative to the Ask and Bid Price in the Saudi Stock Market

\begin{tabular}{|c|c|c|c|c|c|}
\hline Order Flow & OFR $<0.5$ & OFR $=0$ & $0.5<$ OFR $<1$ & OFR $=1$ & OFR $=0.5$ \\
\hline Trade & $\begin{array}{l}\text { Between } \\
\text { Midpoint and } \\
\text { the Ask }\end{array}$ & At Ask & $\begin{array}{l}\text { Between Midpoint } \\
\text { and the Bid Price }\end{array}$ & At Bid & At Midpoint \\
\hline Distribution & $9 \%$ & $40 \%$ & $7 \%$ & $37 \%$ & $7 \%$ \\
\hline
\end{tabular}

Notes: This table shows the distribution of block trade prices in the Saudi Stock Market over the time period 2005-2008. The distribution is determined by the order flow ratio broken into five categories: (1) At the Ask Price, (2) At the Bid Price, (3) At the midpoint (the average of the bid and ask price), (4) Between the midpoint and the ask price, (5) between the midpoint and the bid price.

In order to eliminate the bid-ask bias in block purchases and sales, we employ quotes data to calculate block price impacts instead of transaction prices. Ask (bid) prices are used to compute the price impact for block buys (sells). Mean returns purged of bid-ask bias are displayed in Table 5. We witness that the asymmetry in block purchases and sales seen in Table 3, remains even when we account for the bid-ask bias in block trade transactions. However, the asymmetry is reduced in magnitude for all three price impact measures.

Table 5. Quote Price Effects of Block Trades in the Saudi Stock Market.

$\begin{array}{ccc}\begin{array}{c}\text { Permanent } \\ \text { effects }\end{array} & \begin{array}{c}\text { Total } \\ \text { effects }\end{array} & \begin{array}{c}\text { Temporary } \\ \text { effects }\end{array}\end{array}$

Panel A Buys(n=2,366,099)

Mean

.0090771

.0093398

.0051918

$S D$

$.0131882 \quad 0.011248$

.0096929

Panel A Sell $(n=1,855,236)$

Mean

$-.0091983 \quad-.0096808$

$-.0051626$ 
$S D$

Panel C Test of Equality

difference

t-statistic(two-sample mean comparison test)
.0138164

.0120155

.0101444

$-0.0001212-0.00034$

$1.4 \mathrm{e}+03 * * * \quad 1.7 \mathrm{e}+03 * * *$

.0000292

$1.3 \mathrm{e}+03^{* * *}$

\begin{abstract}
Notes: Mean Returns purged of bid-ask bias surrounding block trades of 10,000 shares or more executed on all companies listed on the Saudi Stock Market over the time period 2005-2008, broken down by buyer (Panel A) and seller (Panel B) initiated trades. Three measures of price impact are reported :(1) Permanent, defined as the algorithmic return of transaction prices from five trade before the block to five trades after;(2) Total, defined as the algorithmic return of transaction prices from five trade before the block to the block trade; and (3) Temporary, defined as the algorithmic return of transaction prices from the block to five trades after the block trade. Panel A reports the buy-block traders while Panel B report sell-block trades along with mean and standards deviations. Panel $\mathrm{C}$ show the tests of equality between the two samples by performing a two-sample mean comparison $t$ test. Standard errors are reported in parentheses. $* * *$ Significant at the $1 \%$ level.
\end{abstract}

\title{
6. Summary and Conclusion
}

In this paper we empirically examine the price impact of block trades, in the Saudi Stock Market over the time period of 2005-2008. Using a unique dataset of intraday data consisting of 2.3 million block buys and 1.9 million block sales, we replicate the asymmetry between block purchases and sales documented in the previous literature. However, unlike prior research the price impact asymmetry persists even when we encapsulate the biases in block transactions through the existence of the bid-ask spread. Overall, our findings suggest that in an emerging market where institutional trading is relatively scarce, market microstructure cannot explain the asymmetry in the price impact of large trades. 
Our results suggest that bid-ask spreads do not fully incorporate the information asymmetry present within block transactions in emerging equity markets. This implies that the electronic limit order book system may not be the optimal trading mechanism for emerging markets. This is because as mentioned by Benveniste et al (1992) and Snell and Tonks (2003) market makers are superior in resolving information asymmetry than the order book system. Our analysis reveals that emerging markets may require a dealership system to improve the quality of their equity markets. Given the extensive trading in emerging equity markets as a result of international diversification, the empirical findings in this paper cannot be ignored. 


\section{References}

ADMATI, A.R. and PFLEIDERER, P., 1988. A theory of intraday patterns: Volume and price variability. Review of Financial Studies, 1, 3-40.

AITKEN, M. and FRINO, A., 1996. Asymmetry in stock returns following block trades on the Australian Stock Exchange: A note. Abacus, 32(1), 54-61.

BENVENISTE, L.M., MARCUS, A.J. and WILHELM, W.J., 1992. What's special about the specialist. Journal of Financial Economics, 32(1), 61-86.

BONSER-NEAL, C., LINNAN, D. and NEAL, R., 1999. Emerging market transaction costs: Evidence from Indonesia. Pacific-Basin Finance Journal, 7(2), 103-127.

CHAN, L. and LAKONISHOK, J., 1993. Institutional trades and intra-day stock price behavior. Journal of Financial Economics, 33(2), 173-199.

CHAN, L.K.C. and LAKONISHOK, J., 1997. Institutional equity trading costs: NYSE versus Nasdaq. JOURNAL OF FINANCE, 52, 713-736.

CHAN, L.K.C. and LAKONISHOK, J., 1995. The behavior of stock prices around institutional trades. JOURNAL OF FINANCE, 50, 1147-1147.

CHIYACHANTANA, C.N., JAIN, P.K., JIANG, C. and WOOD, R.A., 2004. International evidence on institutional trading behavior and price impact. Journal of Finance, 59, 869-898.

CHOE, H., MCINISH, T.H. and WOOD, R.A., 1992. Market microstructure effects on the measurement of the impact of block trades. Working Paper edn. University of Memphis: .

DOMOWITZ, I., GLEN, J. and MADHAVAN, A., 2001. Liquidity, volatility and equity trading costs across countries and over time. International Finance, 4(2), 221-255.

EASLEY, D. and O'HARA, M., 1987. Price, trade size, and information in securities markets. Journal of Financial Economics, 19, 69-90.

ENGLE, R.F. and RUSSELL, J.R., 1998. Autoregressive conditional duration: A new model for irregularly spaced transaction data. Econometrica, 66, 1127-1162.

FRINO, A., MOLLICA, V. and WALTER, T., 2003. Asymmetric price behaviour surrounding block trades: a market microstructure explanation. working paper series No.154 edn. university of Aarhus: CAF, Centre for Analytical Finance.

GEMMILL, G., 1996. Transparency and liquidity: A study of block trades on the London Stock Exchange under different publication rules. Journal of Finance, 51, 1765-1790. 
GHYSELS, E. and CHERKAOUI, M., 2003. Emerging markets and trading costs: Lessons from Casablanca. Journal of Empirical Finance, 10(1-2), 169-198.

GREGORIOU, A., 2008. The asymmetry of the price impact of block trades and the bidask spread. Journal of Economic Studies, 35(2), 191-199.

HOLTHAUSEN, R., LEFTWICH, R. and D. MAYERS, 1987. The Effect of Large Block Transactions on Security Prices: A Cross-Sectional Analysis. Journal of Financial Economics, 19, 237-267.

HOLTHAUSEN, R., LEFTWICH, R. and MAYERS, D., 1990. Large Block Transactions, the Speed of Response, and Temporary and Permanent Stock Price Effects. Journal of Financial Economics, 26, 71-95.

KEIM, D.B. and MADHAVAN, A., 1996. The upstairs market for large-block transactions: Analysis and measurement of price effects. Review of Financial Studies, 9(1), 1-36.

LEASE, R.C., MASULIS, R.W. and PAGE, J.R., 1991. An investigation of market microstructure impacts on event study returns. Journal of Finance, 46, 1523-1536.

LEE, C. and READY, M., 1991. Inferring trade direction from intraday data. Journal of Finance, 46(2), 733-746.

SAAR, G., 2001. Price impact asymmetry of block trades: An institutional trading explanation. Review of Financial Studies, 14(4), 1153-1181.

SNELL, A. and TONKS, I., 2003. A theoretical analysis of institutional investors' trading costs in auction and dealer markets. Economic Journal, 113(489), 576-597.

SPIERDIJK, L., 2004. An empirical analysis of the role of the trading intensity in information dissemination on the NYSE. Journal of Empirical Finance, 11(2), 163-184.

STAPLEDON, G., 1997. Institutional shareholders and corporate governance. Oxford: Clarendon Press.

SUBRAHMANYAM, A., 1991. A theory of trading in stock index futures. Review of Financial Studies, 4(1), 17-51. 